\title{
REPRODUCIBILITY AND THERMAL STABILITY OF COAL-TAR PITCH
}
W. E. Smith
O. J. Horne
B. Napier

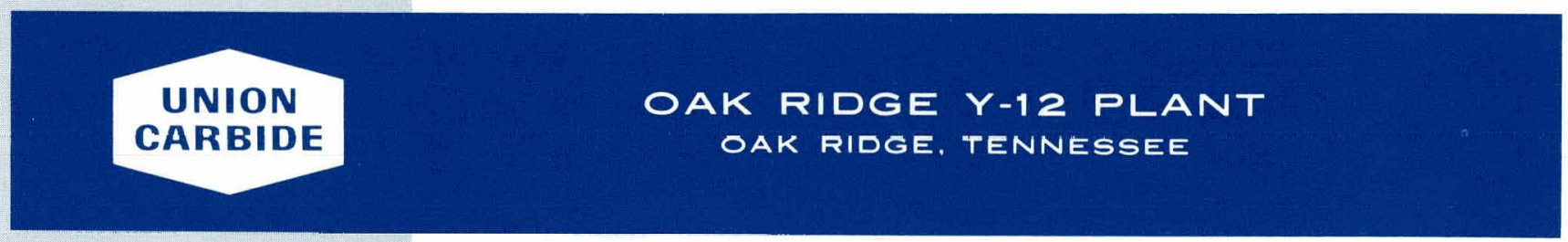

prepared for the U.S. ATOMIC ENERGY COMMISSION

under U.S. GOVERNMENT Contract W.7405 eng 26 


\section{DISCLAIMER}

This report was prepared as an account of work sponsored by an agency of the United States Government. Neither the United States Government nor any agency Thereof, nor any of their employees, makes any warranty, express or implied, or assumes any legal liability or responsibility for the accuracy, completeness, or usefulness of any information, apparatus, product, or process disclosed, or represents that its use would not infringe privately owned rights. Reference herein to any specific commercial product, process, or service by trade name, trademark, manufacturer, or otherwise does not necessarily constitute or imply its endorsement, recommendation, or favoring by the United States Government or any agency thereof. The views and opinions of authors expressed herein do not necessarily state or reflect those of the United States Government or any agency thereof. 


\section{DISCLAIMER}

Portions of this document may be illegible in electronic image products. Images are produced from the best available original document. 
Reference to a company or product name does not imply approval or recommendation of the product by Union Carbide Corporation or the U.S. Atomic Energy Commission to the exclusion of others that may meet specifications.

\begin{tabular}{|} 
Printed in the United States of America. Available from \\
National Technical Information Service \\
U.S. Department of Commerce \\
5285 Port Royal Road, Springfield, Virginia 22151 \\
Price: Printed Copy $\$ 4.00 ;$ Microfiche $\$ 1.45$
\end{tabular}

This report was prepared as an account of work sponsored by the United States Government. Neither the United States nor the United States Atomic Energy Commission, nor any of their employees, nor any of their contractors, subcontractors, or their employees, makes any warranty, express or implied, or assumes any legal liability or responsibility for the accuracy, completeness or usefulness of any information, apparatus, product or process disclosed, or represents that its use would not infringe privately owned rights. 


\title{
REPRODUCIBILITY AND THERMAL STABILITY OF COAL-TAR PITCH
}

\author{
W. E. Smith \\ O. J. Horne \\ B. Napier
}

Oak Ridge Y-12 Plant

P.O. Box Y. Oak Ridge, Tennessee 37830

Date Issued - February 1, 1974

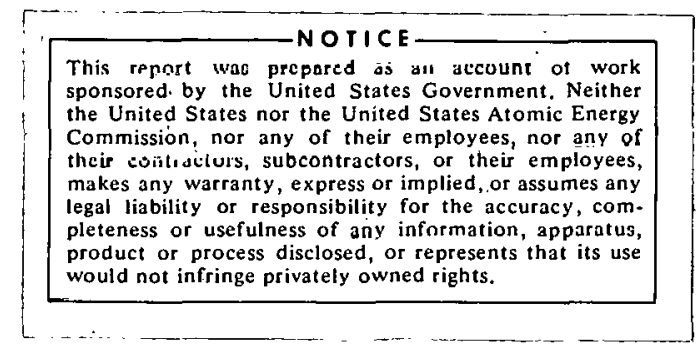

Prepared "for the U.S. Atnmic Energy Commission Under U.S. Government Contract W-7405eng-26 


\begin{abstract}
Two aspects of a coal-tar pitch were studied: (1) reproducibility of the properties of as-received pitch as a function of the sampling period, and (2) changes in the properties that occur on heating the pitch for extended periods at elevated temperature. Reproducibility studies were conducted on twelve samples which had sampling histories that divided them into two groups of six samples each. Data indicated little variability of properties within a sample group, but significant variability between the two groups.

A single lot of coal-tar pitch was analyzed as a function of residence time in an impregnator at $235^{\circ} \mathrm{C}$. Properties reflecting increases in molecular size underwent gradual changes with increasing heating time, but the overall changes after 88 days did not appreciably alter the properties or utility of the pitch.
\end{abstract}




\section{CONTENTS}

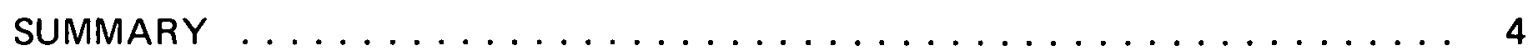

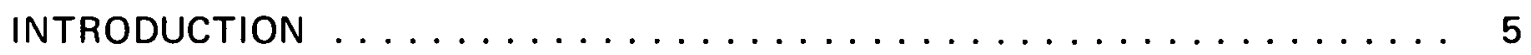

REPRODUCIBILITY AND THERMAL STABILITY OF COAL-TAR PITCH $\ldots \ldots . .6$

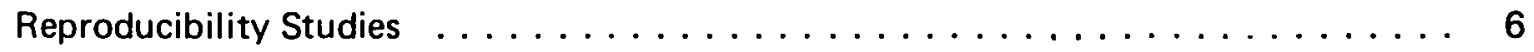

Thermal Stability . . . . . . . . . . . . . . . . . . . . . 6

REFERENCES $\ldots \ldots \ldots \ldots \ldots \ldots \ldots \ldots \ldots \ldots \ldots \ldots \ldots \ldots \ldots$

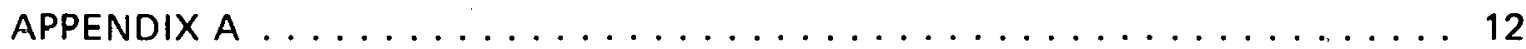

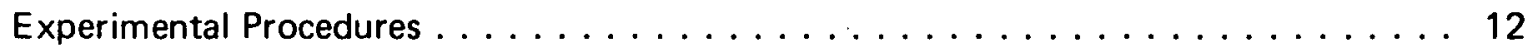

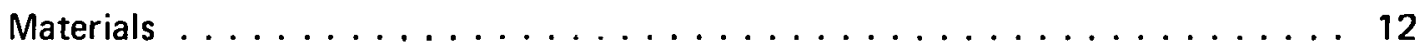

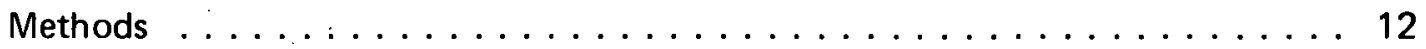

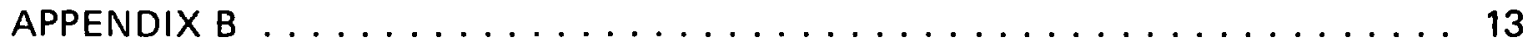

Procedure for Removing Insolubles from Pitches $\ldots \ldots \ldots \ldots \ldots \ldots \ldots \ldots$ 


\section{SUMMARY}

An analytical study was designed: (1) to determine the reproducibility of a coal-tar pitch over an extended production period, and (2) to determine the behavior of the pitch as a function of its residence time in an impregnator at $235^{\circ} \mathrm{C}$. Six samples (5 lots) of the pitch that were in inventory at the beginning of the program were analyzed. Six additional samples (6 lots) were received from the vendor over a period of six months and at a rate of one sample per month. The 12 samples were analyzed for: (1) molecular weight and distribution, (2) softening point, (3) viscosity, (4) benzene insolubles, (5) elemental composition, and (6) coke yield. Nuclear magnetic resonance (NMR) methods were used to determine the distribution of protons between the aromatic and aliphatic constituents. Collectively, these data indicated: (1) significant differences in properties of samples that were already in inventory relative to those that were received from the veridor during the course of the study, but (2) little varlabllity between samples within a respective group.

A single lot of coal-tar pitch was evaluated under imripregnation conditions by analyzing samples as a function of residence time at $235^{\circ} \mathrm{C}$. Data collected after a residence time of 88 days indicated: (1) no change in coke yield, (2) a slight increase in softening point, and (3) a more significant increase in benzene insolubles. 


\section{INTRODUCTION}

This study is part of a continuing effort in carbon precursor technology at the Oak Ridge $Y-12$ Plant $(a)(1-8)$ and consists of an evaluation of coal-tar pitch with respect to reproducibility over a given production period and to thermal stability on continuous heating at elevated temperature. Twelve pitch samples $(11$ lots $)$ were included in the reproducibility study which consisted of a collection of analytical data and statistical treatment of these data. The thermal stability study consisted of monitoring properties of a pitch sample on continuous heating at $235^{\circ} \mathrm{C}$.

Pitch products derived from the destructive distillation of coal have been and continue to be used extensively in industrial extrusion and molding operations, and serve as a source of carbon in furnace and foundry operations. Coal-tar pitches are recovered as residuals after the distillation of light-to-heavy oil fractions from coal tar with approximately two thirds of the coal tar recoverable in pitch form. In general, coal-tar pitches have: (1) relatively high coke yields, (2) relatively low contents of ash and sulfur, (3) a variable content of free carbon, and (4) are usually classified as soft $\left(\mathrm{mp}, 50-70^{\circ} \mathrm{C}\right)$, medium $\left(\mathrm{mp}, 70-90^{\circ} \mathrm{C}\right)$, or hard $\left(\mathrm{mp}>90^{\circ} \mathrm{C}\right)$. $^{(9)}$

Factors which influence the properties of coal-tar-pitch materials include: (1) inherent properties of the coal, (2) conditions used to produce coal tar from coal, and (3) conditions used to produce pitch from coal tar. Data on currently known coal reserves indicate significant differences in composition and physical state for coals in different geographical locations.

Two classifications of coal tars that are produced by the destructive distillation of coal are: (1) retort gas tar which contains 20 - 50 percent free carbon, and (2) oven gas tar which contains $12-20$ percent free carbon. $(10)$ The three primary methods that are used to distill oil fractions from coal tar with the accompanying production of pitch residuals are: (1) distillation to a hard, high-softening-point pitch $\left(150^{\circ} \mathrm{C}\right.$ or higher) and subsequent addition of tar distillates to produce pitch with the desired softening point, (2). distillation under vacuum with steam until pitch of the desired softening point is obtained, and (3) distillation in a horizontal still (without steam or vacuum) until pitch of the desired softening point is oblained. (9)

Though neither of the methods used to prepare the coal tar nor those used to produce pitch from coal tar seem amenable to precise control, mere standardization of procedures would allow some degree of control. However, the variability in the inherent properties of the feedstock materials (coal and coal tar) would probably be reflected in the properties of the pitch, since currently used processing would not tend to compensate for this variability. The product evaluated in this study is a vacuum-distilled pitch with a softening point of $85-90^{\circ} \mathrm{C}$. A description of the materials and methods used in the study are included in Appendix $A$.

(a) Operated by the Union Carbide Corporation's Nuclear Division for the US Atomic Energy Commission. 


\section{REPRODUCIBILITY AND THERMAL STABILITY OF COAL-TAR PITCH}

\section{REPRODUCIBILITY STUDIES}

Some applications utilizing pitch require a high degree of control over material properties and processing conditions. Since the time table in moving from concept to production is usually in terms of years, materials used in high-quality assurance systems must be reproducible throughout the usage period. For this reason, a study was designed to determine the reproducibility of a typical coal-tar pitch (CP 277-15 V) over a period of one year. A single sample (one drum) was to be produced and analyzed each month. After receiving six samples on such a schedule, the proyram was tcrminated because the pitch was II longer available except by special order in quantities of 10,000 pounds or more. In addition to these six sample3, six samples (5 lots) that were alteady in inventory when the sampling program began were analyzed. Collectively, 12 samples (11 ditferent lots) composc this sample group.

Because of the chronology of the samples, the six samples that were in inventory prior to initiation of the sampling study were designated as Group I; the remaining six samples that were procured monthly from the vendor were designated as Group II. Production data associated with the Group I samples could not be ascertained, but were estimated to be 12- 24 months prior to production of the Group II samples. In analyzing the data, efforts were made to determine the variability within the two respective groups as well as between the two groups. Data collected during the study are summarized in Table 1. Analytical methods used in this study are described in Appendix A. Individual data points within Groups I and II all fall within two standard deviations of the respective means (95\% confidence limits) calculated for the properties measured. How much of this variability is associated with the analytical methods is not known. However, differences in properties between groups were large, as can be observed by comparing the mean values for Groups I and $I I$ in Table 1. A test of significance (Student " $t$ " test) at the 95 percent confidence level was used to compare the mean values between Groups I and II. Those properties that do show a significant difference are indicated in Table 1 by an asterisk. As indicated, the Group II samples contained less oxygen but more sulfur and ash than did the Group I samples. In addition, the Group II samples had higher softening points, more insolubles, and higher coke yields than the Group I samples. Molecular-size-distribution data show that the Group II samples had a lower content of high-molecular-weight species (Fraction 4) than the Group I samples, but had a correspondingly higher content of an intermediate species (Fraction 2).

In summary, coal-tar-pitch materials that were received from the vendor in 1972 were quite different from those received at an earlier $(\sim 1970)$ date. It should be stated, however, that samples received during the six-month period in 1972 were quite reproducible. No explanation can be offered for the differences in the 1970 and 1972 products.

\section{THERMAL STABILITY STUDIES}

Pitch materials are commonly used to impregnate carbon structures in order to enhance the bonding in the matrix and/or to densify the structure. Thus, to use liquid impregnation techniques requires that the impregnant be a low-viscosity fluid under processing conditions. 
Table 1

PROPERTIES OF COAL-TAR PITCH

(Type CP 277.15 V)

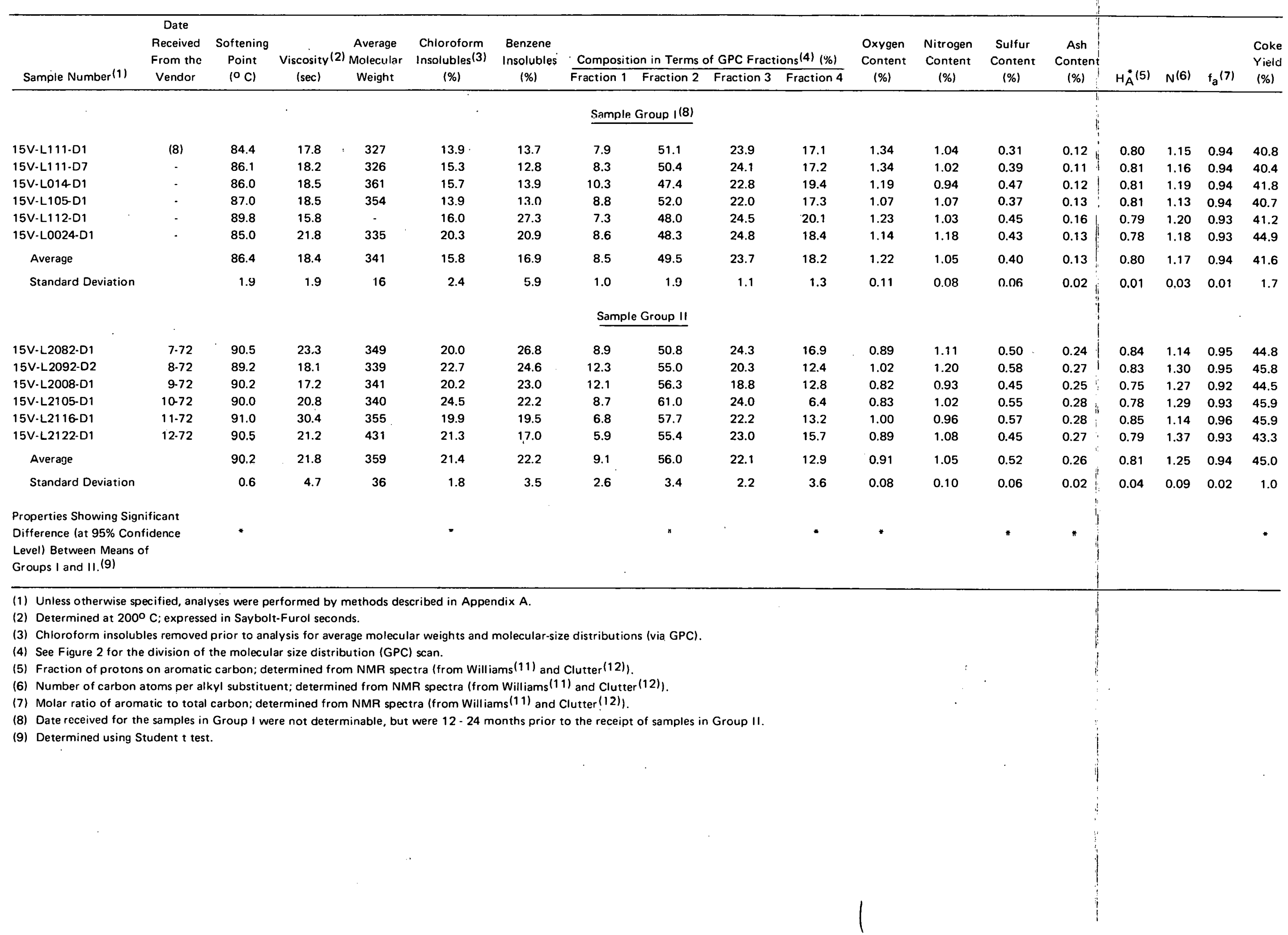


For pitch materials, this property may be obtained by dissolving the pitch in a suitable solvent, or by operating at temperatures sufficient to maintain the pitch as a low-viscosity fluid. While the former is necessary when an elevated temperature is a constraint, the latter is preferable if a maximum amount of pitch is to be deposited per impregnation cycle, such as would be desirable in densification procedures. For this reason, pitch materials are often kept in a molten state over long periods of time, and the constancy of pitch properties under these conditions becomes an important factor in the utility of the pitch as well as in the quality control of the impregnated structures.

Coal-tar pitch (CP 277-15 V; Lot 111; Drums 4 through 7) was evaluated under impregnating conditions covering an 88-day-use cycle. Approximately 220 gallons of pitch were initially placed in an impregnator which was maintained at $235^{\circ} \mathrm{C}$ lor the duration of the study. No pitch was added during the 88-day period, which included approximatcly 50 impregnation cycles eacli uf which was accompanied by evacuation and pressurization sequences. Samples of pitch were taken for analysis after $0,18,34,48,63$, and 88 days. Data were ohtained by the techniques listed in Appendix $A$ and are reported in Table 2.

Some of the properties listed in Table 2 underwent graduated changes during the 88-day period, but overall property changes were relatively small for a heating period of this length. Figure 1, which better illustrates these changes, shows moderate increases in softening points, viscosities (at $200^{\circ} \mathrm{C}$ ), average molecular weights. and benzene insolubles. Such changes would result from loss of volatile constituents and/or from polymerization reactions. Values for benzene insolubles could be influenced by an accumulation of particulate carbon derived from dust on the parts that are submerged in the pitch. As indicated in Figure 1, coke-yield values were quite scattered, but it could be concluded that the cook time had little effect on these values. The GPC scan in Figure 2 shows a typical molecular-size distribution for $15 \mathrm{~V}$ coal-tar pitch and indicates the divisions used in analyzing the GPC data. Gradual changes in molecular-size distributions with increasing cook time are notcd in Figure 3. Values of the fractiunal cumpusition corresponding to the largest (Fraction 4) and smallest (Fraction 1) molecular sizes increased slightly during the test period, while the two fractions of intermediate molecular sizes decreased. These data suggest that both decomposition and polymerization are occurring simultaneously as would be expected when energies are sufficient to disrupt bonds.

In summary, these dald suygust that thls coal-tar-pitch sample underwenl unly gradual changes in properties with increasing time at $235^{\circ} \mathrm{C}$, and further suggest that such a material would have a reasonably long pot life at this impregnating temnerature before property changes were sufficient to require replacement of the impregnant. 
Table 2

PROPERTIES OF COAL-TAR PITCH AS A FUNCTION OF RESIDENCE TIME IN THE IMPREGNATOR AT $235^{\circ} \mathrm{C}$

\begin{tabular}{|c|c|c|c|c|c|c|c|c|c|c|c|c|c|}
\hline \multirow{2}{*}{$\begin{array}{l}\text { Sample } \\
\text { Number }(1)\end{array}$} & \multirow[t]{2}{*}{$"$} & \multirow{2}{*}{$\begin{array}{l}\text { Residence } \\
\text { Time } \\
\text { (days) }\end{array}$} & \multirow{2}{*}{$\begin{array}{l}\text { Softening } \\
\text { Point } \\
\left({ }^{\circ} \mathrm{Cl}\right)\end{array}$} & \multirow{2}{*}{$\begin{array}{c}\text { Viscosity } \\
\text { (sec) }\end{array}$} & \multirow{2}{*}{$\begin{array}{l}\text { Average } \\
\text { Molecular } \\
\text { Weight }(4)\end{array}$} & \multirow{2}{*}{$\begin{array}{c}\text { Benzene } \\
\text { Insolubles (5) } \\
(\%)\end{array}$} & \multicolumn{4}{|c|}{$\begin{array}{l}\text { Composition } \\
\text { as per GPC Fractions (\%) (6) }\end{array}$} & \multirow[b]{2}{*}{$F_{a}(7)$} & \multirow{2}{*}{$\begin{array}{c}H_{A}^{*}(8) \\
(\%)\end{array}$} & \multirow{2}{*}{$\begin{array}{c}\text { Coke } \\
\text { Yield (9) } \\
(\%)\end{array}$} \\
\hline & & & & & & & 1 & 2 & 3 & 4 & & & \\
\hline 15V-L111-PI-1 & & 0 & 88.2 & 19 & 360 & 15 & 8 & 51 & 24 & 17 & 0.93 & 78 & 41 \\
\hline 15V-L111-PI-2 & & 18 & 88.3 & 19 & 360 & 15 & 8 & 52 & 23 & 17 & 0.92 & 76 & 41 \\
\hline $15 V-L 111-P I-3$ & & 34 & 90.4 & 22 & 360 & 15 & 8 & 49 & 25 & 18 & 0.94 & 80 & 42 \\
\hline 15V-L111-PI-4 & & 48 & 90.5 & 23 & 342 & 21 & 8 & 50 & 24 & 18 & 0.92 & 75 & 40 \\
\hline 15V-L111-PI-5 & & 63 & 91.0 & 25 & 388 & 19 & 9 & 49 & 24 & 19 & 0.92 & 76 & 41 \\
\hline $15 \mathrm{~V}-\mathrm{L} 111-\mathrm{PI}-6$ & & 88 & 93.0 & 26 & 376 & 28 & 9 & 48 & 23 & 20 & 0.95 & 81 & 40 \\
\hline
\end{tabular}

(1) Approximately 220 gallons of coal-tar pitch (Cp 277-15V. Lot 111, Drums 4 through 7) were placed in the impregnator. No pitch was added during the study period. Approximately 50 impregnation cycles occurred during the study period, each cycle consisting of an initial evacuation and a subsequent pressurization (80 psi $\mathrm{N}_{2}$ ).

(2) Ring and Ball, ASTM-D-36-66.

(3) Saybolt-Furol viscosity at $200^{\circ} \mathrm{C}$; reported as Saybolt-Furol seconds.

(4) Determined by vapor pressure osmometry; chloroform insolubles (13 - 17\%) removed prior to analysis.

(5) Per ASTM D-2317.

(6) Gel permeation chromatography (GPC) scans were divided into four elution fractions and the area under the curves were determined. Chloroform insolubles (13 - $17 \%$ ) were removed prior to analysis. The fractions correspond to elution counts of $45-48,42-45,39-42$, and $32-39$, respectively.

(7) Molar ratio of the aromatic carbon to the total carbon in the sample. Determined using NMR techniques (from Williams $(11)$ and Clutter(12))

(8) Fraction of protóns on aromatlc Läbur1, detelmined by intogration of NMR sperstra (frnm Williams (11)).

(9) Conradson, ASTM-D-189-65. 


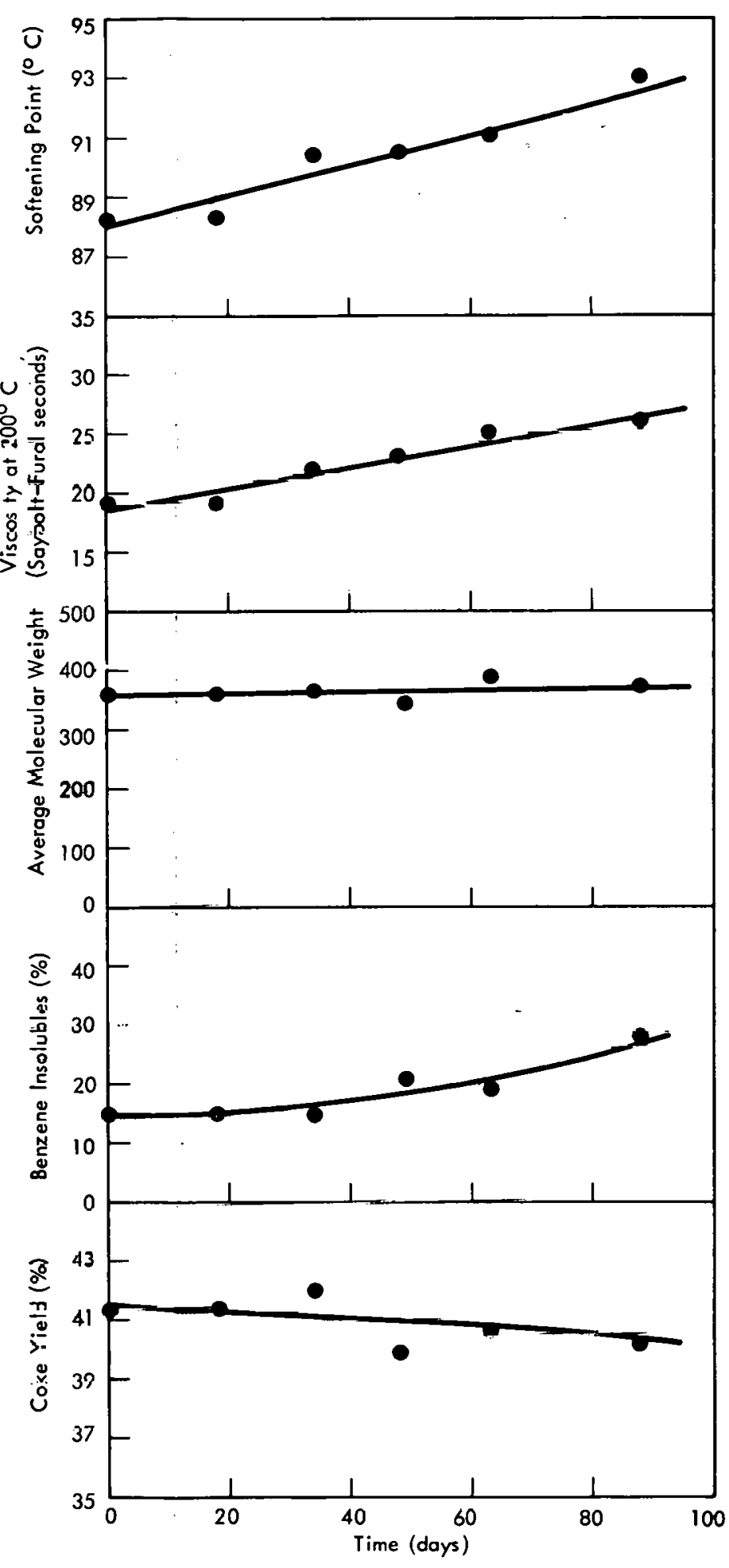

FIgUPe 1. PRÜPERTIES OF COAL-TAR PITCH AS A FUNCTION OF THE RESIDENCE TIME IN THE IMPREGNATOR AT $235^{\circ} \mathrm{C}$. (Type CP 277-15 V)

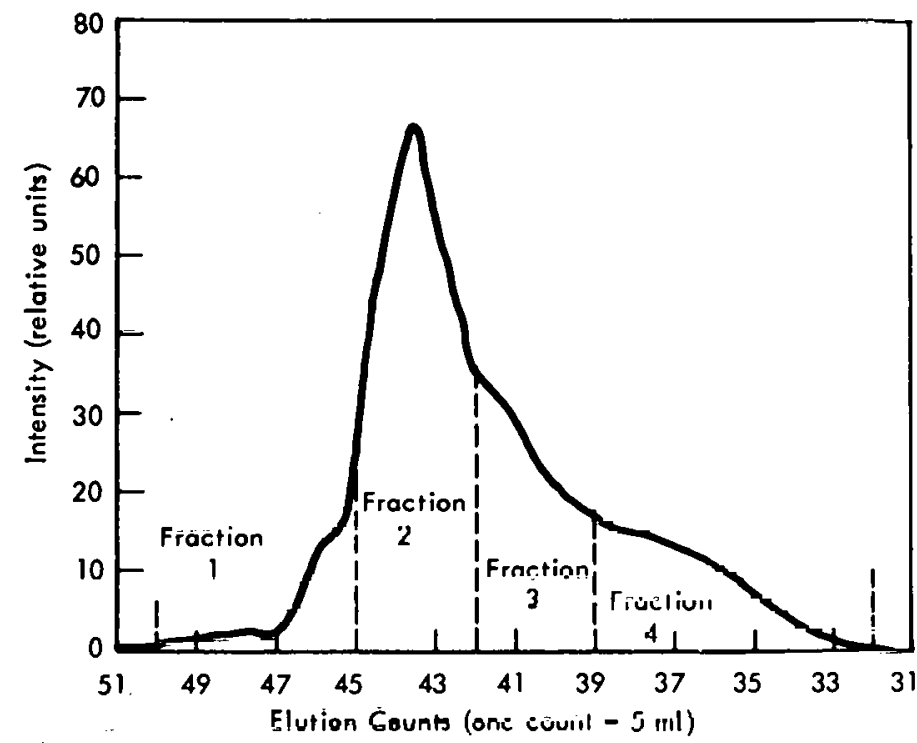

Figure 2. GEL PERMEATION CHROMATOGRAPHIC SCAN SHOWING THE MOLECULAR SIZE DISTRIBUTIÖN OF TYPE CP 277-15 V PITCH.

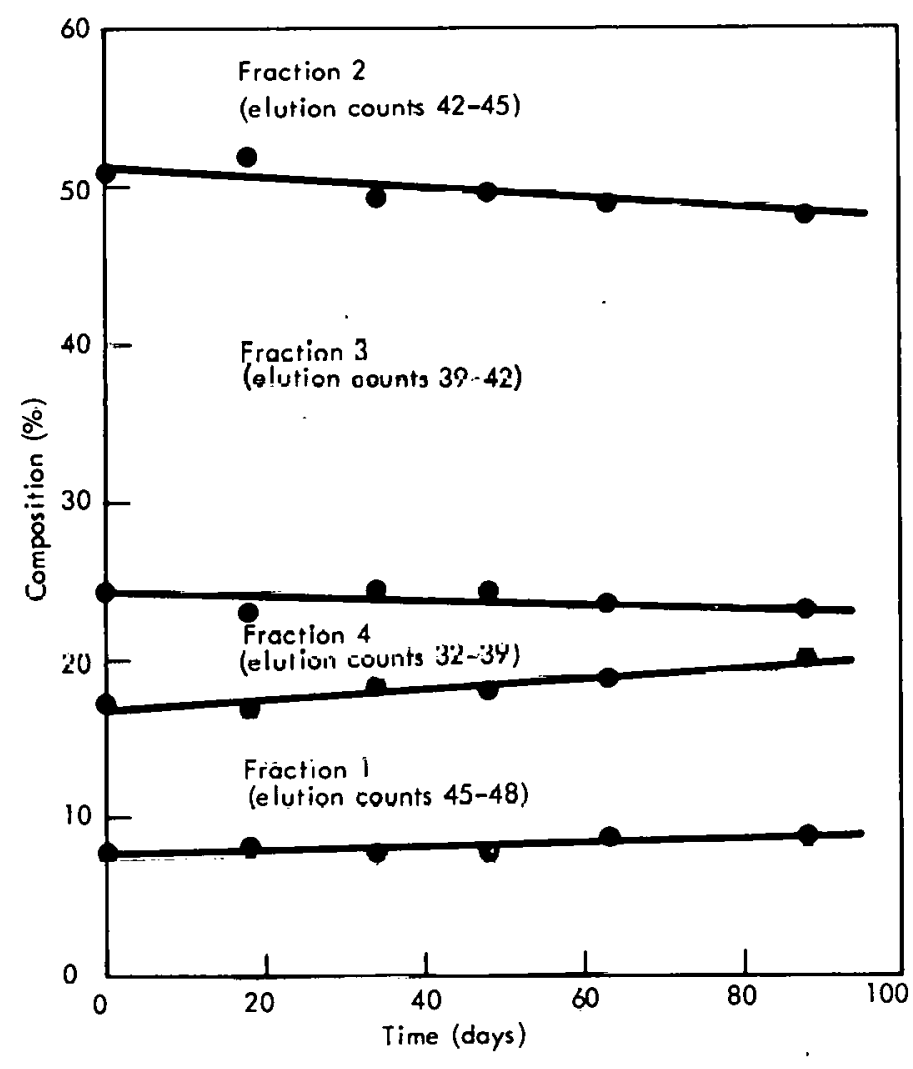

Figure 3. COMPOSITION OF COAL-TAR PITCH BY GEL PERMEATION CHROMATOGRAPHIC ANALYSIS AS A FUNCTION OF THE RESIDENCE TIME IN THE IMPREGNATOR AT $235^{\circ} \mathrm{C}$. 


\section{REFERENCES}

(1) Smith, W. E., Napier, B., and Harper, W. L.; Preparation and Characterization of Hydrocarbon Derivatives of Indene, Y-1712; Union Carbide Corporation-Nuclear Division, Oak Ridge Y-12 Plant, Oak Ridge, Tennessee; April 21,1970.

(2) Smith, W. E., et al; Properties of Carbon Derived from Indene Compounds, Y-1790; Union Carbide Corporation-Nuclear Division, Oak Ridge Y-12 Plant, Oak Ridge, Tennessee; September 15, 1971.

(3) Horne, O. J., Jr; Mesophase Formation in Polymers of Cinnamylideneindene and Acenaphthylene, Y-1799; Union Carbide Corporation-Nuclear Division, Oak Ridge Y-12 Plant, Oak Ridge, Tennessee; August 18, 1971.

(4) Overholser, L. G.; NERVA Fuel Element Development Program Summary Report-July 1966 through June 1972: Precursor Carbon and Molded Graphite Studies, Y-1857; Union Carbide Corporation-Nuclear Division, Oak Ridge Y-12 Plant, Oak Ridge, Tennessee; April 6, 1973.

(5) Smith, W. E.; NERVA Fuel Element Development Program Summary Report - July 1966 through June 1972: Carbons Derived from Organic Compounds, Y-1868; Union Carbide Corporation-Nuclear Division, Oak Ridge Y-12 Plant, Oak Ridge, Tennessee; February 3, 1973.

(6) Horne, O. J., Smith, W. E., and Napier, B; Properties of Carbon Derived from Petroleum Pitches, Y-1875; Union Carbide Corporation-Nuclear Division, Oak Ridge Y-12 Plant, Oak Ridge, Tennessee; June 21, 1973.

(7) Horne, O. J., Smith, W. E., and Napier, B.; Properties of Carbon Derived from Acenaphthylene and Cinnamylideneindene, Y-1880; Union Carbide CorporationNuclear Division, Oak Ridge Y-12 Plant, Oak Ridge, Tennessee; December 7, 1973.

(8) Smith, W. E., Horne, O. J., and Napier, B.; Characterization and Reproducibility of Petroleum Pitches, Y-1921; Union Carbide Corporation-Nuclear Division, Oak Ridge $Y$-12 Plant, Oak Ridge, Teninessee; to be issued.

(9) Mantell, C. L.; Carbon and Graphite Handbook, p 234; Interscience Publishers, New York (1968).

(10) Ibid; p 232.

(11) Williams, R. B.; ASTM Special Technical Publication 224, pp 168-194 (1958).

(12) Clutter, D. R., et al; Analytical Chemistry, 44, p 1395 (1972). 


\section{APPENDIX A}

\section{EXPERIMENTAL PROCEDURES}

\section{Materials}

The coal-tar-pitch samples evaluated in this study were a product of Allied Chemical Company, and represented various lots of a pitch designated CP 277-15 V.

\section{Methods}

Descriptions of the analytical procedures used in this study are as follows:

1. Softening points were determined by the ring-and-ball method as per ASTM D-36-66. Visual ubservatiuns of the meltiry prucesses irivulved use of a Fisher-Juhns melting-point block.

2. Viscosities were measured at $200^{\circ} \mathrm{C}$ by the Saybolt-Furol viscosimeter as per ASTM D-88-56.

3. Average-molecular-weight data were obtained using a Hewlett-Packard Model 302 vapor pressure osmometer. Sucrose octaacetate was used as a standard. Prior to analysis, chloroform insolubles were removed by a standard procedure (see Appendix B). Samples were analyzed as tetrahydrofuran solutions.

4. Benzene insolubles were determined as per ASTM D-2317.

5. Gel permeation chromatography (GPC) data were obtained using a Waters Associates Model 200 GPC with columns packed with Styragel (styrene-divinylbenzene polymer). Prior to analysis, chloroform insolubles were removed by a standard procedure (see Appendix B). Samples were analyzed as tetrahydrofuran solutions.

6. Oxygen and nitrogen contents were determined by neutron activation analysis using a Kaman Model 711 neutron generator and beryllium as a standard.

7. Analysis of the sulfur contents involved combustion in a bomb followed by a gravimetric determination of sulfur as barium sulfate.

8. Ash contents were determined by firing samples to $900^{\circ} \mathrm{C}$ in air and weighing the residuals.

9. Nuclear magnetic resonance (NMR) studies were conducted using a Bruker HFX-15, 90megaHertz spectrometer. Tetramethylsilane was used as an internal standard. Samples were analyzed as five percent solutions in carbon tetrachloride.

10. Coke yields were determined by the Conradson method as per ASTM D-189-65. 


\section{APPENDIX B}

\section{PROCEDURE FOR REMOVING INSOLUBLES FROM PITCHES}

The following procedure was used to remove insolubles from $\mathrm{CP}$ 277-15 V pitch prior to GPC and average-molecular-weight determinations:

1. Weigh two 0.5-gram aliquots of powdered pitch into 500-milliliter boiling flasks having ground-glass joints.

2. Add 200 milliliters of chloroform to each flask.

3. Using water condensers, reflux for $11 / 2$ hours.

4. Transfer to 400-milliliter beakers and evaporate to dryness at room temperature.

5. Add 200 milliliters of chloroform to the dried samples and again evaporate to dryness at room temperature.

6. Add 200 milliliters of chloroform to the dried samples and agitate thoroughly.

7. Filter the samples through a tared, fine-porosity-fritted glass funnel using Teflon for the seal between the funnel and vacuum flask.

8. Rinse each beaker and funnel with $\mathbf{5 0}$ milliliters of chloroform.

9. Dry the fritted funnels containing the insolubles at $50^{\circ} \mathrm{C}$ under house vacuum for 30 minutes, cool in a desiccator, and weigh. Calculate percent chloroform insolubles, reporting the average of the two aliquots.

10. Transfer the filtrate to 400 -milliliter beakers and evaporate to dryness at room temperature under house vacuum.

11. Use liquid nitrogen to break up the dry, chloroform-soluble pitch.

12. Transfer to glass bottles and dry overnight at room temperature under house vacuum. 


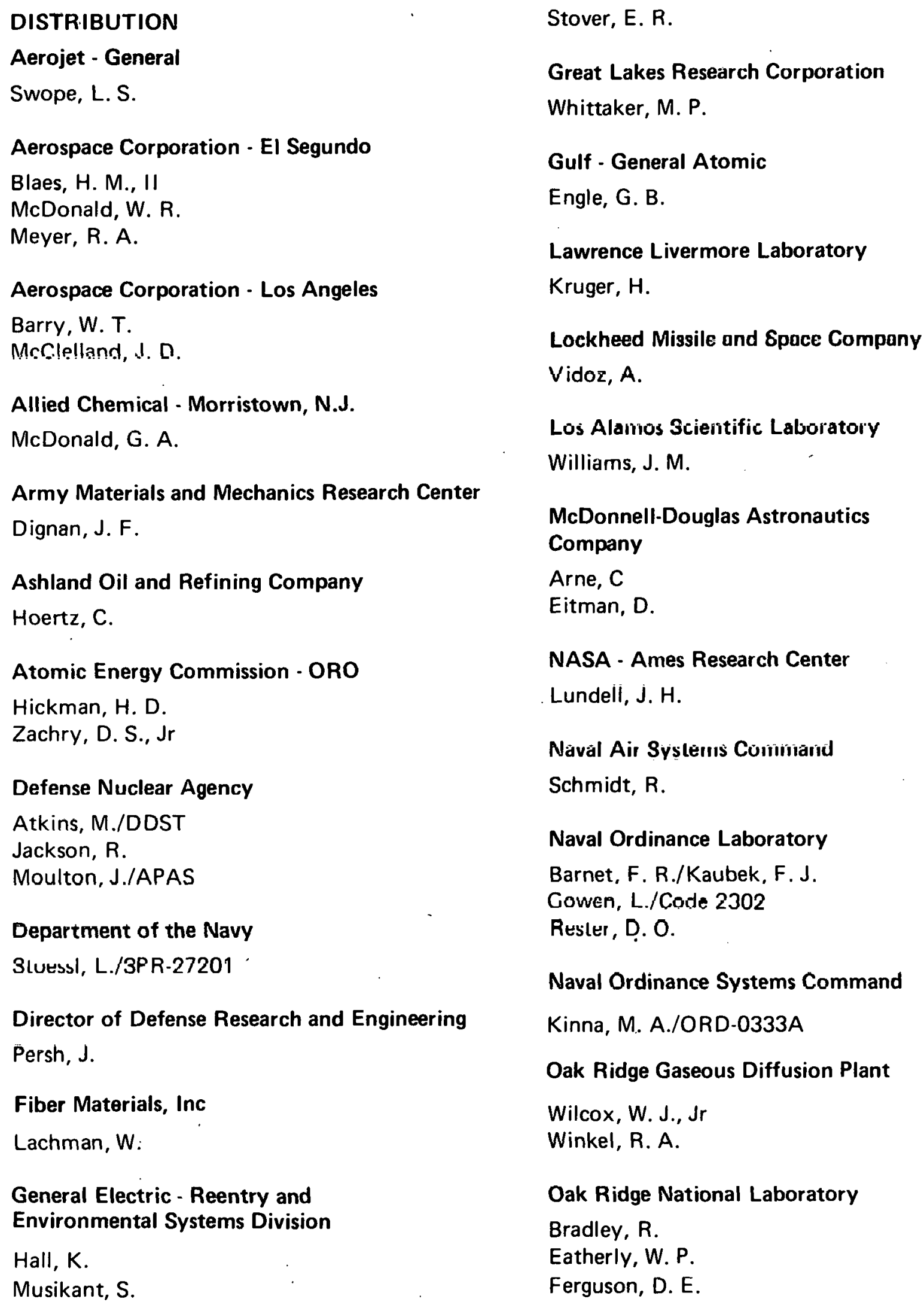


Scott, J. L.

Weir, J. R.

Oak Ridge Y-12 Plant

Ardary, Z. L.

Briscoe, O.W.

Burditt, R. B.

Burkhart, L. E.

Denny, A.

Horne, O. J., Jr (5)

Keith, Alvin

Kite, H. T.

Lambdin, F.

Lundin, M. I.

Marrow, G. B.

McLendon, J. D.

Napier, B., Jr (2)

Napier, J. M.

Phillips, L. R.

Pollock, C. B.

Schreyer, J. M.

Smith, R. D.

Smith, W. E. (5)

Valentine, $K$.

Weathersby, W. E.

Williams, R. D.

Yaggi, W. J.

$Y-12$ Central Files (5)

$Y-12$ Central Files (master copy)

$Y-12$ Central Files (route)

$Y-12$ Central Files (Y-12RC)

Paducah Gaseous Diffusion Plant

Levin, R. W.

Penn State University

Walker, P. L., Jr
Quaker Oats Company - John Stuart

Research Laboratory

Brown, L. H.

Watson, D.

\section{SAMSO}

Green, G./RSF

Mentzer, D./RSSR

Shover, D./RSSE

Sandia - Albuquerque

Auerbach, I.

McDonald, J. E.

Pèurifoy, R. L., Jr

Zimmerman, J. C.

Sandia - Livermore

Rychnovsky, R. E.

Union Carbide Corporation - Carbon Products Division

Browning, J. B.

Singer, L.

Townsend, H. N.

Union Carbide Corporation - Chemical and Plastics Division

Shechter, L.

University of Washington

Fishbach, D. B.

Wright-Patterson Air Force Base

Materne, H. A.

Pratt, C./MAAS

Schmidt, D./I NC.

In addition, this report is distributed with the category. UC-4, Chemistry, as given in the USALC Standard Distribution Lists for Unclassified Scientific and Technical Report, TID-4500. 